\section{Why do we pay for information that we won't use? A cognitive-based explanation for genetic information seeking}

European Journal of Human Genetics (2016) 24, 625; doi:10.1038/ejhg.2015.188; published online 9 September 2015

More than half a million people worldwide have purchased Direct-toConsumer (DTC) genetic tests. A survey conducted in the US in 2010 indicated that $70-80 \%$ of respondents are willing to pay for DTCs ${ }^{1}$ even if the results do not have immediate clinical value. A 2009 online survey of more than 1000 social networking users found that $64 \%$ of them were interested in buying a genetic test to obtain useful health information. ${ }^{2}$

By providing individuals with information about their genetic predisposition to a variety of diseases, DTCs are supposed to influence healthcare use and to motivate beneficial behavior change. However, the few available studies that have investigated the users' response to DTCs have found that:

- people generally adapt well to the information received, ${ }^{3}$ having no significant short term effects in 'psychological health, diet or exercise behavior, or use of screening tests'. ${ }^{4}$

- people do not significantly change their behavior as the result of genetic risk information. ${ }^{4}$

- changes are related to a subjective interpretation of risk. ${ }^{5}$

A 2010 Cochrane Collaboration systematic review, concluded thus: 'Claims that receiving DNA-based test results motivates people to change their behavior are not supported by evidence'. ${ }^{6}$

Choices are guided by cognitive and emotional processes, so what is it that takes place in our mind that disposes us to spend money on information that we'll never use? Other than the well-known statistical illiteracy, ${ }^{7}$ we argue that the decision to buy a genetic test may be a consequence of a self-signaling action. A self-signaling action is one chosen partly to secure good news about one's traits or abilities, even when the action has no causal impact on these traits and abilities. ${ }^{8}$ Moreover, thanks to the optimistic bias ${ }^{9}$ we believe that we are less at risk of experiencing a negative event than are other people. Confirmation bias does the rest, inducing the tendency to search for, interpret, or recall information in a way that only serves to confirm our beliefs or hypotheses. ${ }^{10}$

These observations highlight the importance of increasing the knowledge and awareness of consumers, rather than regulating the DTC market, so as to render them able to use the acquired knowledge in an effective way instead of transforming it into biased (and useless) knowledge.

\section{CONFLICT OF INTEREST}

The authors declare no conflict of interest.

Alessandra Gorini* and Gabriella Pravettoni ${ }^{\star}$ Department of Health Science, University of Milan and European Institute of Oncology, Milan, Italy E-mail: alessandra.gorini@unimi.itorgabriella.pravettoni@ieo.it

1 Neumann PJ, Cohen JT, Hammitt JK et al: Willingness-to-pay for predictive tests with no immediate treatment implications: a survey of US residents. Health Econ 2012; 21 : 238-251.

2 McGuire AL, Diaz CM, Wang T, Hilsenbeck SG: Social networkers' attitudes toward direct-to-consumer personal genome testing. Am J Bioeth 2009; 9: 3-10.

3 Green RC, Roberts JS, Cupples LA et al: Disclosure of APOE genotype for risk of Alzheimer's disease. N Engl J Med 2009; 361: 245-254.

4 Bloss CS, Schork NJ, Topol EJ: Effect of direct-to-consumer genomewide profiling to assess disease risk. N Engl J Med 2011; 364: 524-534.

5 Kaufman DJ, Bollinger JM, Dvoskin RL, Scott JA: Risky business: risk perception and the use of medical services among customers of DTC personal genetic testing. J Genet Couns 2012; 21: 413-422.

6 Marteau TM, French DP, Griffin SJ et al: Effects of communicating DNA-based disease risk estimates on risk-reducing behaviours. Cochrane Database Syst Rev 2010; CD007275.

7 Gaissmaier W, Gigerenzer G: Statistical illiteracy undermines informed shared decision making. Z Evid Fortbild Qual Gesundhwes 2008; 102: 411-413.

8 Bodner R, Prelec D: Self-signaling and diagnostic utility in everyday decision making. In: Brocas I, Carillo J (eds): Collected Essays in Psychology and Economics. Oxford University Press, 2002.

9 Sharot T: The optimism bias. Curr Biol 2011; 21: R941-R945.

10 Jones M, Sugden R: Positive confirmation bias in the acquisition of information. Theory Decis 2001; 50: 59-99. 